Han Jing-Sheng. 1990. Use of antitranspirant epidermal coatings for plant protection in China. Plant Dis. 74:263-266.

Homma, Y., Y. Arimoto, and T. Misato. 1981 Effect of sodium bicarbonate on each growth stage of cucumber powdery mildew fungus (Sphaerotheca fuliginea) in its life cycle. J. Pesticide Sci. 6:201-209.

Horst, R.K., S.O. Kawamoto, and L.L. Porter. 1992. Effect of sodium bicarbonate and oils on the control of powdery mildew and black spot of roses. Plant Dis. 76:247-251.
Kamp,M. 1985. Control of Erysiphe cichoracearum on Zinnia elegans with a polymer-based antitranspirant. HortScience 20:879-881

Koul, A.K. 1980. Powdery mildew on Euonymus japonica in Kashmir. Indian Phytopathol. 21:507-508.

Nadernejad, N. 1966 Euonymus japonicus in gardening. Iran J. Plant Pathol. 3:21-24.

Tokushige, Y. 1953. The effect of powdery mildew on Euonimus japonicus. Ann. Phytopathol. Soc. Jpn. 17:61-64.
Ziv, O. and R.A. Frederiksen. 1986 The effect of film-forming antitranspirants on leaf rust and powdery mildew incidence on wheat. Plant Pathol. 36:242-245.

Ziv, O. and A. Hagiladi. 1984. Control of powdery mildew on hydrangea and crape myrtle with antitranspirants. HortScience 19:708-709.

Ziv, O. and T.A.Zitter. 1992. Effect of bicarbonates and film-forming polymers on cucurbit foliar diseases. Plant Dis. 76:513-517.

\title{
Adsorption, Desorption, and Leaching of Oxadiazon in Container Media and Soil
}

\section{Glenn R. Wehtje ${ }^{1}$, Charles H. Gilliam ${ }^{2}$, and Ben F. Hajek ${ }^{3}$ Alabama Agricultural Experiment Station, Auburn University, AL 36849}

Additional index words. herbicides, weed control, ornamentals, environmental contamination

\begin{abstract}
Adsorption of ${ }^{14} \mathrm{C}$-labeled oxadiazon was evaluated in three soilless media and a mineral soil at concentrations between 0.1 and $100 \mathrm{mg} \cdot \mathrm{kg}^{-1}$. Adsorption, which was at least $96 \%$, was not influenced by absorbent type (medium vs. soil) or by oxadiazon concentration. However, desorption was greater in the media than in the soil. After five water extractions, $5.4 \%$ of the applied oxadiazon was recovered from media, but only $0.4 \%$ was recovered from the soil. In the soil and in two of the media, leaching with water failed to displace oxadiazon $2 \mathrm{~cm}$ below the surface to which it had been applied. No oxadiazon was detected below $4 \mathrm{~cm}$ in the third medium. Oxadiazon is sufficiently adsorbed to resist leaching-based displacement. Oxadiazon is not likely to enter the environment by escaping from treated containers. Chemical name used:3-[2,4-dichloro-5-(1-methylethoxy)phenyl]5-(1,1-di-methylethyl)-1,3,4-oxadiazol-2-(3H)-one (oxadiazon).
\end{abstract}

Producing nursery crops in containers is a common practice. This system generally uses a potting medium that is composed of organic materials such as pine bark, peatmoss, rice hulls, wood shavings, sawdust, and other waste products in lieu of soil. Compared with soil, media offer the advantages of less weight, better drainage, increased porosity (which promotes root exploration), and improved sanitation with respect to soil-borne diseases and weeds. Yet, due to infestation via wind, irrigation water, or both, weeds remain a problem, which necessitates using herbicides.

Container nurseries use large volumes of irrigation water due to the porosity of media. Throughout the growing season in the southeastern United States, containers are typically irrigated daily with 13 to $18 \mathrm{~mm}$ of water using

Received for publication $24 \mathrm{Feb}$. 1992. Accepted for publication 24 Aug. 1992. Alabama Agricultural Experiment Station Journal Series no. 11-923258. Use of trade names does not imply endorsement of the products named nor criticism of similar ones not named. The cost of publishing this paper was defrayed in part by the payment of page charges. Under postal regulations, this paper therefore must be hereby marked advertisement solely to indicate this fact. 'Associate Professor, Dept. of Agronomy and Soils. ${ }^{2}$ Professor, Dept. of Horticulture.

${ }^{3}$ Professor, Dept. of Agronomy and Soils. overhead sprinklers (Fare et al., 1992). Growers and extension personnel have suggested that irrigation runoff from nurseries may be a source of pesticide contamination for local water supplies and surrounding water bodies. Water contamination as a result of pesticides may be the result of accidental direct pesticide application to the water, the erosion of media containing absorbed pesticides into irrigation runoff, and the movement of dissolved pesticides in the irrigation water as it percolates through the media and drains out of the container.

Few reports on herbicide leachability in container media have been published. Horowitz andElmore (1991), using a bentgrass (Agrostis stolonifera L.) bioassay for herbicide detection, evaluated the adsorption and leaching of 2-chloro-1-(3-ethoxy-4-nitrophenoxy)-4-(trifluoromethyl)benzine (oxyfluorfen) in various soilless media and two nonamended agricultural soils. Peat was four to five times more absorptive of oxyfluorfen than redwood bark, such that oxyfluorfen was leached much less in media with relatively more peat. Oxyfluorfen leaching was greater in media comprised of 3 bark : 1 sand than in native soil. In the media evaluated, leaching was related more to oxyfluorfen application rate than to water volume. Moles and Whitcomb (1976), using a wheat bioassay, reported that oxadiazon did not leach below $7.5 \mathrm{~cm}$ when applied to the surface of various peat and bark media and watered daily over 6 weeks.

Herbicide adsorption on media or soil is the primary mechanism by which leaching is resisted (Bailey and White, 1970). Thus, sufficient adsorption, which limits leachability, is desirable. However, complete and irreversible adsorption would eliminate any herbicide uptake by the target weed, thereby rendering it void of any preemergence activity. For an herbicide to provide preemergence activity, some degree of desorption must occur (Wauchope and Koskinen, 1983).

Oxadiazon is used extensively in container production (Bailey and Simmons, 1979), where it offers preemergence control of various weeds, including lesser-seeded bittercress (Cardamine oligosperma Nutt.), common yellow woodsorrel (Oxalis stricta L.), common purslane (Portulaca oleracea L.), Pennsylvania smartweed (Polygonum pensylvanicum L.), annual bluegrass (Poa annua L.), and crabgrass [Digitaria sanguinalis (L.) Scop.]. The maximum registered application rate is $4.4 \mathrm{~kg}$ a.i./ha. Oxadiazon water solubility is $0.70 \mathrm{ppm}$. Further, oxadiazon has been reported to be strongly adsorbed by soil colloids and humus, such that very little migration or leaching occurs in soil (Humburg, 1989). The objectives of this study were to evaluate and compare the adsorption, desorption, and mobility of oxadiazon in soilless container media and in a mineral soil. Radiolabeled oxadiazon $\left({ }^{14} \mathrm{C}\right)$ was used to facilitate herbicide detection.

General procedures. Three media, typical of those used in the southeastern United States, were characterized by standard analytical procedures (Gardner, 1986) as to their mineral and organic-matter content, cation-exchange capacity, bulk density, and water-holding capacity (Table 1). The gravimetric water-holding capacity and water-holding capacity at 30 $\mathrm{kPa}$ were determined (Gardner, 1986). A mineral soil (Marvyn, sandy loam, Typic Kanhapaludults) was also included.

If oxadiazon is applied at $4.4 \mathrm{~kg}$ a.i./ha (i.e. $44 \mu \mathrm{g} \cdot \mathrm{cm}^{-2}$ ) to the surface of a medium that has an average bulk density of $0.33 \mathrm{~g} \cdot \mathrm{cm}^{-3}$ (average for the three media used in this study), and if there is even distribution in the top $1 \mathrm{~cm}$ of the medium through irrigation turbulence, the resulting oxadiazon concentration on a dryweight basis would be $\approx 133 \mathrm{mg} \cdot \mathrm{kg}^{-1}$. Theoretically, this would represent the highest concentration in the medium. Ring ${ }^{14} \mathrm{C}$-labeled oxadiazon was used to facilitate detection within this concentration range. The specific 
activity was $1.11 \mathrm{MBq}$. A completely random design with four replications was used with all experiments. Data from each experiment were subjected to analysis of variance, and treatment means were separated by the appropriate LSD value at $P=0.05$.

Adsorption and desorption. Oxadiazon sorption was evaluated in each medium and the soil using a soil-solution technique (Patterson et al., 1982), during which sufficient water was added to the media samples $(1.2 \mathrm{~kg})$ to bring each to field capacity (FC). $\mathrm{FC}$ - the amount of water held against the force of gravity expressed on a percent weight basis - had been determined previously for the media and soil (Table 1) using the method described by Adams et al. (1982). Appropriate amounts of formulated (Ronstar 2L) and ${ }^{14} \mathrm{C}$-labeled oxadiazon were added to the substrates to achieve $0.1,1.0,10.0$, and 100.0 $\mathrm{mg} \cdot \mathrm{kg}^{-1}$ (dry-weight basis) and then mixed in thoroughly. Samples were sealed in plastic bags to prevent evaporation and allowed to equilibrate for $48 \mathrm{~h}$ at $30 \mathrm{C}$. This length of time is commonly used in soil-solution work (Adams et al., 1982); our previous trials with thin-layer chromatography indicated that no degradation occurred during this period (unpublished data). After equilibration, samples were divided into four soil-solution extraction cups and compacted by applying pressure $(275 \mathrm{kPa})$ with a piston attached to a modified drill press. The extraction cups were plexiglass pipe with an 8 $\mathrm{cm}$ i.d. The bottom plate was perforated, a characteristic that allowed the soil solution to escape and be collected in the lower catch cup. Samples were centrifuged for $3 \mathrm{~h}$ at $2500 \mathrm{rpm}$. Subsamples $(1 \mathrm{ml})$ of the extracted soil solution were assayed for ${ }^{14} \mathrm{C}$ using liquid scintillation spectrometry (LSS) (Wang et al., 1975). The fraction of oxadiazon in the soil solution was determined by multiplying the amount of radioactivity in this $1 \mathrm{ml}$ of soil solution by the total amount of water that had been added to bring the sample to FC, and dividing by the total amount of radioactivity (dpm) originally added to the sample. The amount of radioactivity for each milliliter of solution extracted from a medium ranged from 75 to $150 \mathrm{dpm}$; counting efficiency ranged from $94 \%$ to $97 \%$.

A similar procedure was used to evaluate oxadiazon desorption. Sufficient water was added to bring $100 \mathrm{~g}$ of field soil and $300 \mathrm{~g}$ of medium 1 to FC. Nonlabeled and ${ }^{14} \mathrm{C}$-labeled $\left(\approx 10^{5} \mathrm{dpm}\right)$ oxadiazon were added at 100 $\mathrm{mg} \cdot \mathrm{kg}^{-1}$ on a dry-weight basis. After $24 \mathrm{~h}$ of equilibration, the soil solution was extracted by centrifugation as described above. The amount of medium solution was recorded and two $1-\mathrm{ml}$ subsamples were taken for ${ }^{14} \mathrm{C}$ quantification. The extracted medium solution was discarded, and the sample was returned to FC with additional water and then allowed to equilibrate for an additional $24 \mathrm{~h}$. These procedures were repeated until five extractions had been performed. The total amount of oxadiazon recovered over these repeated cycles of equilibration and extraction was then determined.

Mobility. Oxadiazon mobility was evaluated in each medium with a column-leaching

Table 1. Mechanical and physical properties and water-holding capacity of the substrates used in oxadiazon adsorption studies.

\begin{tabular}{|c|c|c|c|c|c|c|c|c|}
\hline \multirow[b]{3}{*}{ Substrate ${ }^{x}$} & & & & \multirow{3}{*}{$\begin{array}{c}\text { Ignition }^{2} \\
\text { wt loss } \\
(\%)\end{array}$} & \multicolumn{4}{|c|}{ Physical properties } \\
\hline & \multicolumn{3}{|c|}{ Composition (\%) } & & \multirow{2}{*}{$\begin{array}{c}\text { CEC } \\
\left(100 \mathrm{meq} \cdot \mathrm{g}^{-1}\right)\end{array}$} & \multirow{2}{*}{$\begin{array}{c}\text { Bulk } \\
\text { density } \\
\left(\mathrm{g} \cdot \mathrm{cm}^{-3}\right)\end{array}$} & \multicolumn{2}{|c|}{$\begin{array}{l}\text { Water-holding } \\
\text { capacity }(\%)\end{array}$} \\
\hline & Sand & Silt & Clay & & & & Grav" & $30 \mathrm{kPa}$ \\
\hline \multicolumn{9}{|l|}{ Medium } \\
\hline 1 & $\ldots v$ & $\ldots$ & $\ldots$ & 85 & 20.60 & 0.20 & 167 & 113 \\
\hline 2 & $\ldots$ & $\ldots$ & $\ldots$ & 32 & 32.04 & 0.56 & 101 & 36 \\
\hline 3 & $\ldots$ & $\ldots$ & $\ldots$ & 95 & 36.27 & 0.24 & 115 & 124 \\
\hline Soil & 77.3 & 15.7 & 7.0 & 1.3 & 6.50 & 1.30 & 12 & 11 \\
\hline
\end{tabular}

${ }^{\mathrm{X}} \mathrm{A}$ determination of organic matter.

${ }^{y} \mathrm{CEC}=$ cation exchange capacity.

${ }^{\times}$Medium $1=1$ rice hulls : 1 peat : 1 pine bark : 2 wood shavings (by volume); medium $2=7$ pine bark : 1 sand $(\mathrm{v} / \mathrm{v})$; medium $3=3$ pine bark : 1 peat $(\mathrm{v} / \mathrm{v})$; field soil = Marvyn sandy loam, Typic kanhapaludults. "Grav = gravimetric water-holding capacity.

'Insufficient amounts to quantify.

technique (Harris, 1967). Polyvinylchloride pipe was cut into 2 -cm sections. Eight sections were taped together end to end and nylon mesh was positioned over the column bottom. Columns were filled to the sixth section with medium and then preconditioned by infiltrating each column with $400 \mathrm{ml}$ of water, allowing the columns to drain for $12 \mathrm{~h}$ and equilibrate at FC before using. Nonlabeled and ${ }^{14} \mathrm{C}$-labeled oxadiazon $\left(\approx 10^{6} \mathrm{dpm}\right)$ were added to additional medium to achieve a concentration of $1.0 \mathrm{mg} \cdot \mathrm{kg}^{-1}$, along with sufficient water to bring the medium to FC. This oxadiazon-dosed medium was used to fill the columns to the seventh section. Columns were placed in beakers and leached with $200 \mathrm{ml}$ of water, which was added in $25-\mathrm{ml}$ increments over $1 \mathrm{~h}$. Subsamples $(1 \mathrm{ml})$ of the leachate were collected and assayed for radioactivity by LSS Columns were frozen and sectioned by cutting through the taped joint with a serrated knife. The medium in each column section was transferred to beakers, allowed to thaw, then mixed. Two 1-g subsamples were assayed for radioactivity by LSS.

Adsorption and desorption. Oxadiazon adsorption was at least $96 \%$ regardless of substrate type and oxadiazon concentration (Table 2). Oxadiazon adsorption in the soil was the same as that observed in the three media. And as with the media, adsorption was not affected by the oxadiazon concentration, a result that indicated that the adsorptive capacity had not been exceeded.

In the desorption experiment, each consecutive extraction removed an average of 96 $\mathrm{ml}$, or $57 \%$ of the available water, from medium 1 and $6 \mathrm{ml}$, or $50 \%$ of the available water, from the soil (Table 3). In the medium, the first extraction removed almost $2 \%$ of the original oxadiazon; each consecutive extraction removed progressively less, for a total of $5.4 \%$. In contrast, each extraction removed an average of only $0.08 \%$ of the original amount of oxadiazon from the soil. The amount recovered was equal for all extractions, and the cumulative amount recovered was less than one-tenth of that for the medium.

With a simple equilibration and extraction experiment, the adsorptivity of oxadiazon by soil seemed to be similar to that observed with medium 1 ( $99 \%$ vs. $96 \%$ ), but with repeated cycles of equilibration and extraction, the
Table 2. Amount of oxadiazon in soil solution as influenced by media, soil, and oxadiazon concentration. ${ }^{2}$

\begin{tabular}{ccccc}
\hline & \multicolumn{4}{c}{ Oxadiazon concn $\left(\mathrm{mg} \cdot \mathrm{kg}^{-1}\right)$} \\
\cline { 2 - 4 } Substrate & 0.1 & 1.0 & 10.0 & 100.0 \\
\hline Medium & \multicolumn{5}{c}{ Absorbed $(\%)$} \\
1 & 98 & 97 & 97 & 96 \\
2 & 99 & 99 & 99 & 99 \\
3 & 98 & 98 & 98 & 98 \\
Soil & 99 & 98 & 99 & 99 \\
\hline
\end{tabular}

${ }^{{ }^{2} \mathrm{LSD}_{0.05}}$ between any two means $=4.0$.

Medium composition is described in Table 1.

Table 3. Desorption of oxadiazon from soil and media at field capacity and containing oxadiazon at $10 \mathrm{mg} \cdot \mathrm{kg}^{-1}$ (dry-weight basis) with repeated extractions of the soil solution.

\begin{tabular}{lcc}
\hline & \multicolumn{2}{c}{ Oxadiazon removed $^{\mathrm{x}}(\%)$} \\
\cline { 2 - 3 } Extraction $^{x}$ & Medium $1^{y}$ & Soil \\
\hline 1 & 1.89 & 0.09 \\
2 & 1.10 & 0.08 \\
3 & 0.95 & 0.08 \\
4 & 0.84 & 0.08 \\
5 & 0.61 & 0.09 \\
Total & 5.39 & 0.42 \\
\hline
\end{tabular}

Each extraction removed an average of $96 \mathrm{ml}(57 \%)$ of the $167 \mathrm{ml}$ of water that had been added to the medium, and $6 \mathrm{ml}(50 \%)$ of the $12 \mathrm{ml}$ that had been added to the soil. After each extraction, fresh water was added back to the medium or soil to replace that removed by extraction. Equilibration time between each extraction was $24 \mathrm{~h}$. $\mathrm{LSD}_{0.0}$ between any two values $=0.05$.

'1 Rice hulls : 1 peat : 1 pine bark : 2 wood shavings (by volume).

${ }^{\mathrm{x}} \mathrm{LSD}_{0.05}$ between any two values within a common medium during the five extractions was 0.16 for medium 1 and 0.02 for soil.

Table 4. Relative mobility of oxadiazon in media and soil as determined by column leaching.

\begin{tabular}{lcccc}
\hline Distance & \multicolumn{4}{c}{ Oxadiazon recovered (\%) } \\
\cline { 2 - 5 } $\begin{array}{l}\text { from } \\
\text { surface } \\
(\mathrm{cm})\end{array}$ & \multicolumn{4}{c}{ Medium } \\
\cline { 2 - 5 } & 1 & 2 & 3 & Soil \\
\hline $0-2$ & $54^{y}$ & 99 & 99 & 99 \\
$3-4$ & 46 & $<1$ & $<1$ & $<1$ \\
$5-10$ & $<1$ & $<1$ & $<1$ & $<1$ \\
\hline
\end{tabular}

${ }^{2}$ Media and soil compositions are described in Table 1.

${ }^{y} S_{D_{0.05}}$ between any two means $=8.0$. 
greater adsorptivity of soil and resistance to desorption became readily apparent. The greater retention of oxadiazon by the soil more likely is attributable to its minimal waterholding capacity than to physical or compositional factors. Soil FC was less than one-tenth that of the medium (12\% vs. 167\%). Consequently, in each cycle of equilibration-extraction, much less water was involved in the soil relative to the medium.

As noted, using oxadiazon at the recommended rate will result in an approximate concentration of $132 \mathrm{mg} \cdot \mathrm{kg}^{-1}$. Assume further that the medium is wetted to FC (i.e., $128 \%$, the average value for the three media used), and that $97 \%$ of the herbicide is absorbed by the medium and thereby rendered unavailable for uptake by the weeds. The resultant aqueous oxadiazon concentration that the weeds would be exposed to is $4 \mathrm{mg} \cdot$ liter $^{-1}$, which is above the amount soluble in water and is adequate for controlling weeds. In previous trials (unpublished data), oxalis and prostrate spurge ( $E u$ phorbia supina Raf.) seeds exposed to an oxadiazon concentration of $\leq 1 \mathrm{mg} \cdot \mathrm{liter}^{-1}$ under hydroponic conditions did not germinate.

Mobility. In soil and media 2 and 3, no oxadiazon was detected below the first $3-\mathrm{cm}$ increment (Table 4). In medium 1, oxadiazon was detected only in the first two increments. The limited mobility observed in these studies concurs with earlier research in which a wheat bioassay was used to detect herbicides (Moles and Whitcomb, 1976). The greater mobility of oxadiazon in medium 1 cannot be attributed to any of the medium's mechanical or physical properties (Table 1). Medium 1 was the only medium that contained wood shavings and, therefore, was coarser than the others. Further, these wood shavings tended to float during leaching, and this may have increased downward herbicide displacement through simple mechanical displacement. Oxadiazon movement in container media is limited and the herbicide is not likely to enter as a solute into irrigation runoff. However, it can be displaced by absorption to the "fines" of the media and, therefore, be rendered unavailable. Oxadiazon adsorption remains high regardless of whether the adsorbent is medium or soil. However, especially in medium, this adsorption seems to be somewhat reversible. Weed control activity in container-grown nursery crops probably reflects this desorption in that each irrigation probably results in "pulses" of oxadiazon entering solution where it can be absorbed by germinating weed seeds.

\section{Literature Cited}

Adams, F., C. Bumester, N.V. Hue, and L.F. Long. 1982. A comparison of column displacement and centrifuge methods of obtaining soil solution. Soil Sci. Soc. Amer. Proc. 44:733-735.

Bailey, G.W. and J.L. White. 1970. Factors influ- encing the adsorption, desorption, and movement of pesticides in soil, p. 29-92. In:F. Gunther and J. Gunther (eds.). Residue Revs. vol. 32. Springer-Verlag, New York.

Bailey, R.E. and J.A. Simmons. 1979. Oxadiazon for weed control in woody ornamentals. Weed Sci. $27: 396-400$.

Fare, D.C., C.H. Gilliam, and G.J. Keever. 1992. Monitoring irrigation at container nurseries, HortTechnology 2(1):75-78.

Gardner, W.H. 1986. Water content. In: A. Klute (ed.). Methods of soil analysis. Part 1: Physical and mineralogical methods. Spec.Publ. 9, Amer. Soc. of Agron. Madison, Wis.

Harris, C.I. 1967. Movement of herbicides in soil. Weeds 15:214-216

Horowitz, M. and C.L. Elmore. 1991. Leaching of oxyfluorfen in container media. Weed Technol. 5:175-180.

Humburg, N.E. (ed.). 1989. Herbicide handbook. Weed Sci. Soc, of Amer, p. 199-200.

Moles, A. and C.E. Whitcomb. 1976. Movement of Ronstar in containers as influenced by growing media. Southern Nurserymen Assn. Res. Conf., Annu. Rpt. 21:137.

Patterson, M.G., G.A. Buchanan, R.H. Walker, and R.M. Patterson. 1982. Fluometuron in soil solution as an indicator of its efficacy in three soils. Weed Sci. 30:688-691.

Wang, C.H., D.L. Willis, and W.D. Loveland. 1975. Radiotracer methodology in biological science. Prentice-Hall, Englewood Cliffs, N.J.

Wauchope, R.D. and W.C. Koskinen. 1983. Adsorption-desorption of herbicides in soil: A thermodynamic perspective. Weed Sci. 31:504 512. 